\title{
A survey of management practices on Irish dairy farms with emphasis on risk factors for Johne's disease transmission
}

\author{
Aideen E Kennedy ${ }^{1,2}$, Eugene F O'Doherty ${ }^{1}$, Noel Byrne ${ }^{1}$, Jim O'Mahony ${ }^{2}$, E M Kennedy ${ }^{1}$ and Riona G Sayers ${ }^{1 *}$
}

\begin{abstract}
Background: Johne's disease (JD) is a chronic granulomatous enteritis affecting ruminants. A number of farm management practices are associated with increased risk of JD transmission. The aim of the current study was to document JD-related management practices currently employed on Irish dairy farms.

Survey questions focused on calving area (CA), calf and manure management. Independent variables (region, calving-season, enterprise type, herd size and biosecurity status) were used to examine influences on JD associated dependent variables (survey questions). Additionally general biosecurity practices were also examined.

Results: Results showed management practices implemented by Irish dairy farmers pose a high risk of JD transmission. Of the farmers surveyed, 97\% used the CA for more than one calving, 73.5\% and $87.8 \%$ pooled colostrum and milk respectively, 33.7\% never cleaned the CA between calving's, and 56.6\% used the CA for isolating sick cows. Survey results also highlighted that larger herds were more likely to engage in high risk practices for JD transmission, such as pooling colostrum (OR 4.8) and overcrowding the CA (OR 7.8). Larger herds were also less likely than smaller herds to clean the CA (OR 0.28), a practice also considered of risk in the transmission of JD.

Conclusion: Many management practices associated with risk of JD transmission were commonly applied on Irish dairy farms. Larger herds were more likely to engage in high risk practices for JD transmission. Control programmes should incorporate educational tools outlining the pathogenesis and transmission of JD to highlight the risks associated with implementing certain management practices with regard to JD transmission.
\end{abstract}

Keywords: Johne's disease, Survey, Management practices, Biosecurity

\section{Background}

Johne's disease (JD), a chronic granulomatous enteritis of ruminants, is caused by the bacterium Mycobacterium avium subspecies paratuberculosis (MAP) [1]. Significant economic losses have been reported on cattle farms due to infection with MAP. Such losses are primarily due to decreased slaughter value [2], reductions in milk production in dairy cows [3], sub-optimal fertility [4], and an increase in cow replacement costs [5]. The impact of JD on animal health and on-farm profitability has led to considerable interest in the control of MAP at farm level. Controlling JD however proves difficult due

\footnotetext{
* Correspondence: riona.sayers@teagasc.ie

${ }^{1}$ Animal \& Bioscience Research Department, Animal \& Grassland Research and Innovation Centre, Teagasc, Moorepark, Fermoy, Co. Cork, Ireland Full list of author information is available at the end of the article
}

to the variable progression from sub-clinical to clinical stages of disease, combined with diagnostic difficulties especially in the early stages of infection [6]. As test and cull programmes alone prove largely ineffective in eradicating MAP from a herd [7], incorporation of improved calf management practices, including calf-related hygiene, may prove of more benefit in reducing on farm prevalence [8].

Infection with MAP predominantly occurs in calves, with animals less than six months of age being most susceptible [9]. The severity and rate of JD progression in individual animals are dependent on the MAP exposure dose and the age of the animal at infection [10]. Infection usually occurs via the faecal-oral route, although inutero transmission can occur [11]. Doré E, Paré J, Côté G, Buczinski S, Labrecque O, Roy J and Fecteau G [12], 
concluded that exposure of calves to adult faeces is the most important risk factor in MAP transmission. Faecaloral transmission is facilitated by faecal contamination of a calf's environment and feedstuffs, with the primary environmental risk factors for neonatal infection being faecal contamination of the udder or calving pens [13]. Colostrum and milk from infected cows can also contain quantities of MAP capable of infecting calves $[14,15]$. Feeding of pooled colostrum from multiple cows [14], and feeding milk containing antibiotic residues to calves [16], are also both considered to increase the risk of MAP infection within a herd.

Additional management-related risk factors for MAP transmission include group housing of periparturient cows [17], the presence of more than one cow in a calving pen [18], use of group calving pens [19], faecal contamination of udders of periparturient cows [20], and use of maternity pens that are not cleaned between each calving [21]. Larger sized herds [17,22-24], are associated with an increased risk of testing MAP ELISA positive. Allowing young-stock access to pasture contaminated with adult manure can also be considered a risk factor due to the prolonged survival of MAP in slurry [25]. Finally, biosecurity [26,27], is an essential component of disease prevention in general, and is equally important in the prevention of JD, with purchase of animals considered a significant route of MAP transmission between farms [28].

Concern has been raised regarding the zoonotic potential of MAP [29] a potential link between MAP and Crohn's disease in humans having been postulated. Proof of a causal link would have important consequences for the global dairy industry [30]. The possible public health implications of MAP make it incumbent on milk producing nations to minimise the risk of consumers ingesting MAP contaminated milk. The most recent estimate of JD herd exposure prevalence in Irish cattle is approximately $20 \%$ [31], which compares favourably with estimates in other European countries [32]. Additionally, between the years of 1995 and 2002 only 232 clinically infected animals (an average of approximately 30 animals per year in a cattle population of approximately six million) were detected by the Irish Department of Agriculture, Food and the Marine laboratories (DAFM) [33]. Although a relatively low prevalence is reported, the dairy industry plays a critical role in Ireland's economy [34] and as such a JD pilot control programme has been embarked upon to further reduce the levels of MAP in Irish cattle. This Animal Health Ireland (AHI) [35] co-ordinated programme uses risk assessment and management plans (RAMPs) as an integral part of the scheme [1]. These risk assessments involve evaluation of four key JD risk areas namely, management of preweaned heifers, management of heifers to first calving, mature cow environment and hygiene, and management of the calving area.

Investigations into herd demographics [36] and risk factors associated with introduction and transmission of JD and testing JD positive on Irish dairy farms have previously been conducted [37,38]. The risk factors identified in these studies included larger herd size [38], importation of cattle from abroad [36,38], and not using individual calving pens [37]. These findings are in agreement with the international studies described previously. Although risk factors for testing positive for MAP have been identified in Ireland, a national survey documenting the prevalence of application of JD risk-associated management practices at farm level has not previously been reported. Such a study may highlight underlying reasons for Ireland's relatively low prevalence of JD test positive individuals and herds. The aim of the current study, therefore, was to document utilisation of management factors associated with JD transmission on Irish dairy farms, based on both national and international risk data, using a geographically representative group of Irish dairy farms. This will provide a baseline for JD risk in Ireland, which can subsequently be used to allow targeting of specific management practices that require improvement as part of control programmes. Key influences on the application of JD-associated management factors were also investigated.

\section{Methods}

\section{Survey procedure}

The survey was conducted as a postal survey with survey packs containing a cover letter, a self-addressed envelope, and a questionnaire, mailed to participants for completion and return. The study population included farmers that participated in a larger disease prevalence study, the selection of whom has previously been outlined by O'Doherty E, Sayers R and O'Grady L [39]. In brief, 500 randomly selected members of HerdPlus (a breeding management decision support tool co-ordinated by the Irish Cattle Breeding Federation [ICBF]) were invited to participate. Selection was based on stratified proportional sampling using strata of herd size and geographical location. A total of 312 herds elected to participate in the study with participation entirely voluntary and non-incentivised. The study population has previously been shown to be geographically representative of Irish dairy herds [39]. The overall project was approved by the Moorepark ethics committee in November 2008.

\section{Survey questionnaire}

Questions were compiled based on information gathered from peer-reviewed publications, a commercially available web-based herd-health management tool [2], and 
Teagasc researcher experience of Irish dairying systems. Following consultation with researchers at the Animal and Grassland Research and Innovation Centre, Teagasc (Irish Agriculture and Food Development Authority) and piloting of the questionnaire by farm managers based at seven Teagasc research farms, a number of minor modifications were made to the questionnaire prior to circulation to study participants. The final questionnaire consisted of an initial section containing 17 JD-associated questions (Table 1) and a second section containing a further 30 questions examining general bioexclusion and biocontainment (collectively referred to as biosecurity) management practices (Figure 1). Johne's disease associated questions related to the calving-area (CA) and CA hygiene, milk and colostrum management, and access of young calves and in-calf heifers to adult faeces. These survey questions (dependent variables) were presented in a closed format with three response options offered, namely Yes (Y), No (N), or Sometimes (S). A subset of the population (approximately 10\%) was resurveyed in order to quantify the Sometimes responses. Where Sometimes was chosen as an answer, an extra closed question was asked with the options of either $\mathrm{A}=<50 \%$ of the time or $\mathrm{B}=>50 \%$ of the time offered (Table 1). Biosecurity-related questions were again presented as closed questions offering Yes and No binary responses.

\section{Descriptive analysis and herd classification}

Hardcopy survey responses were entered into an online survey software package (www.surveymonkey.com) with electronic inputs being manually checked against hardcopy versions. Coded responses to each question were subsequently downloaded and Microsoft Excel (MS Office, Version 2010) used to organise the data, fix variables for directionality, and complete descriptive analysis.

Questionnaires were deemed suitable for analysis if greater than two thirds of survey questions were answered. Based on Irish Central Statistics Office [40] data, study herds were assigned to two geographical regions i.e. dairy dense (southern region) and non-dense (northern region), with herd calving-season categorised as springcalving (i.e. $\geq 85 \%$ of the herd calved between January and March) and non-spring-calving (calving at other times of year). The livestock enterprise type was classified as dairy only or mixed-species livestock herds (i.e. herds that also contained beef cattle and/or sheep), with herd size categorised as small (31 to 65 cows), medium (66 to 99 cows), or large ( $>99$ cows). The bioexclusion classification of each herd i.e. open (free movement of new purchases onto the farm) or closed (no introduction of new purchases onto the farm) was available from a parallel study as were a number of additional management factors [39].

\section{Statistical analysis}

Chi-squared, logistic regression and correlation (Pearson and Spearman) analyses were completed using Stata data analysis and statistical software (Version 12). Prior to statistical analysis an initial model was created with 'sometimes' response options excluded. This allowed direct comparison between those answering definitively 'yes' or 'no' (Model 1). In the interest of completeness, survey response options were also dichotomised yielding two further datasets for analysis i.e. Model $2=\mathrm{Y}+\mathrm{S}$ versus $\mathrm{N}$ and Model $3=\mathrm{Y}$ versus $\mathrm{S}+\mathrm{N}$. A total of five herd classification independent variables (i.e. region, calving-season, enterprise type, herd size, bioexclusion status) were used to examine key influences on JD risk variables. As a first step, a univariable (Pearson's Chi-squared) analysis was completed. Independent variables recording $\mathrm{P} \leq 0.15$ were included in logistic regression models (1, 2 and 3 ). A manual backwards elimination with a forward step was applied to each model with significant variables $(\mathrm{P} \leq 0.05$ chosen as accepted significance level) retained in the final model. Pearson's correlation was used to check for colinearity across independent variables. Spearman's rank correlation $\left(r_{s}\right)$ was performed to examine relationships between dependent variables (JD survey questions) with $r_{s}$ values of $>0.3$ reported. Biosecurity variables were not statistically analysed.

\section{Results}

\section{JD questionnaire descriptive and statistical analysis}

A total of 306 farmers returned JD questionnaires suitable for analysis yielding a 98\% response rate. Following exclusion of six questionnaires as incomplete, non-responders for individual JD questions ranged from two to nine participants. The majority of study herds (67\%) were located in the dairy dense region of Ireland. Of the participating herds, $27 \%$ were categorised as small, $31 \%$ as medium, and $42 \%$ as large herd size. Similar to the national trend in the Republic of Ireland [41,42], spring-calving systems were operated by $87 \%$ of study herds, with $52 \%$ operating mixed livestock enterprises. A total of 54 herds (17.7\%) were categorised as closed [39]. As results from Model 1 (Table 2) represented farmers that were definitive in responding either Yes or No to survey questions, this model is discussed in detail. Comparable associations, however, were observed in all three Models (Table 2 and Additional file 1).

\section{Calving area (CA) variables}

Only 3\% of study farms avoided frequent use the CA for more than one calving at a time. Overcrowding of the $\mathrm{CA}$, on at least an occasional basis, was reported by over $40 \%$ of respondents (having five or greater cows in the $\mathrm{CA}$ at any one time was cited in the questionnaire as an example of overcrowding following questionnaire 
Table 1 JD Questionnaire responses

\begin{tabular}{|c|c|c|c|c|c|c|}
\hline \multirow{2}{*}{\multicolumn{2}{|c|}{$\begin{array}{l}\text { Que. Management variable } \\
\text { Calving area (CA) management }\end{array}$}} & \multirow[t]{2}{*}{$n$} & \multirow[t]{2}{*}{ Response } & \multirow[t]{2}{*}{ Outcome (\%) } & \multicolumn{2}{|c|}{$\begin{array}{l}\text { If sometimes chosen- what } \% \\
\text { of the time?* }\end{array}$} \\
\hline & & & & & A: Less than $50 \%$ & B: More than $50 \%$ \\
\hline \multirow[t]{3}{*}{1} & \multirow{3}{*}{$\begin{array}{l}\text { Is the CA frequently used for more than one calving at } \\
\text { any one time? }\end{array}$} & \multirow[t]{3}{*}{303} & No & 3 & & \\
\hline & & & Sometimes & 27 & $x$ & \\
\hline & & & Yes & 70 & & \\
\hline \multirow[t]{3}{*}{2} & \multirow{3}{*}{$\begin{array}{l}\text { Is the CA overcrowded? (e.g. more than five cows in calving } \\
\text { pen at any one time) }\end{array}$} & \multirow[t]{3}{*}{302} & No & 57.6 & & \\
\hline & & & Sometimes & 29.1 & $x$ & \\
\hline & & & Yes & 13.2 & & \\
\hline \multirow[t]{3}{*}{3} & \multirow{3}{*}{$\begin{array}{l}\text { Is the CA cleaned out between every calving and bedded } \\
\text { with clean dry bedding? }\end{array}$} & \multirow[t]{3}{*}{300} & No & 33.7 & & \\
\hline & & & Sometimes & 37 & $x$ & \\
\hline & & & Yes & 29.3 & & \\
\hline \multirow[t]{3}{*}{4} & \multirow[t]{3}{*}{ Is the CA used to house sick cows? } & \multirow[t]{3}{*}{297} & No & 42.4 & & \\
\hline & & & Sometimes & 54.9 & $x$ & \\
\hline & & & Yes & 2.7 & & \\
\hline \multirow[t]{3}{*}{5} & \multirow[t]{3}{*}{ Do cows have manure soiled legs and udders? } & \multirow[t]{3}{*}{300} & No & 43.3 & & \\
\hline & & & Sometimes & 51 & $x$ & \\
\hline & & & Yes & 5.7 & & \\
\hline \multicolumn{7}{|c|}{ Calf feeding management } \\
\hline \multirow[t]{3}{*}{6} & \multirow{3}{*}{$\begin{array}{l}\text { Do new born calves stay with mother in CA for more than } \\
\text { six hours? }\end{array}$} & \multirow[t]{3}{*}{304} & No & 17.1 & & \\
\hline & & & Sometimes & 39.5 & $x$ & \\
\hline & & & Yes & 43.4 & & \\
\hline 7 & Is the calf allowed to suckle from the cow? & 303 & No & 7.3 & & \\
\hline & & & Sometimes & 32.7 & & $x$ \\
\hline & & & Yes & 60.1 & & \\
\hline 8 & Is colostrum collected without disinfection of the teats prior & 301 & No & 23.3 & & \\
\hline & to collection? & & Sometimes & 25.9 & $50: 50$ & \\
\hline & & & Yes & 50.8 & & \\
\hline 9 & Are heifer replacement calves fed with pooled colostrum? & 302 & No & 26.5 & & \\
\hline & & & Sometimes & 27.8 & $x$ & \\
\hline & & & Yes & 45.7 & & \\
\hline 10 & Are heifer replacement claves fed pooled surplus milk from & 303 & No & 12.2 & & \\
\hline & & & Sometimes & 25.1 & $x$ & \\
\hline & & & Yes & 62.7 & & \\
\hline 11 & Are heifer replacement calves fed milk from sick and mastitic cows? & 304 & No & 40.5 & & \\
\hline & & & Sometimes & 33.9 & $x$ & \\
\hline & & & Yes & 25.7 & & \\
\hline Manur & e management & & & & & \\
\hline 12 & Is milk and feed area for calves contaminated with cow manure? & 302 & No & 88.7 & & \\
\hline & & & Sometimes & 10.6 & $50: 50$ & \\
\hline & & & Yes & 0.7 & & \\
\hline 13 & Do calves have direct contact with cows and their manure & 300 & No & 78.3 & & \\
\hline & prior to weaning? & & Sometimes & 13 & $50: 50$ & \\
\hline & & & Yes & 8.7 & & \\
\hline
\end{tabular}


Table 1 JD Questionnaire responses (Continued)

\begin{tabular}{|c|c|c|c|c|c|}
\hline \multirow[t]{3}{*}{14} & \multirow{3}{*}{$\begin{array}{l}\text { Do calves have access to pasture which has had cow slurry } \\
\text { applied in the same season? }\end{array}$} & \multirow[t]{3}{*}{302} & No & 27.8 & \multirow{3}{*}{$x$} \\
\hline & & & Sometimes & 53.6 & \\
\hline & & & Yes & 18.5 & \\
\hline \multirow[t]{3}{*}{15} & \multirow{3}{*}{$\begin{array}{l}\text { Do heifers have direct contact with cows and their manure } \\
\text { prior to entering milking herd? }\end{array}$} & \multirow[t]{3}{*}{302} & No & 21.9 & \multirow{3}{*}{$50: 50$} \\
\hline & & & Sometimes & 40.7 & \\
\hline & & & Yes & 37.4 & \\
\hline \multirow[t]{3}{*}{16} & \multirow[t]{3}{*}{ Is water and feed area for heifers contaminated with cow manure? } & \multirow[t]{3}{*}{302} & No & 75.2 & \multirow{3}{*}{$x$} \\
\hline & & & Sometimes & 14.9 & \\
\hline & & & Yes & 9.9 & \\
\hline \multirow[t]{3}{*}{17} & \multirow{3}{*}{$\begin{array}{l}\text { Do heifers have access to pasture which has had cow slurry } \\
\text { applied in the same season? }\end{array}$} & \multirow[t]{3}{*}{304} & No & 11.5 & \multirow{3}{*}{$x$} \\
\hline & & & Sometimes & 57.9 & \\
\hline & & & Yes & 30.6 & \\
\hline
\end{tabular}

${ }^{*}$ A subset of the population was re-surveyed to quantify the Sometimes responses. $X$ indicates the response chosen by the majority of the subpopulation, $50: 50$ indicating an equal number choosing $\mathrm{A}$ or $\mathrm{B}$.

piloting). Larger sized herds were more likely to overcrowd the CA compared to small (OR 7.8) or medium sized (OR 5.0) herds. Over two thirds of the participating farmers did not clean and bed the CA between calvings. Smaller herds however were more likely to engage in cleaning and bedding of the CA (OR 3.6) compared to larger herds. Sick cows were housed in the calving area by over half of all respondents.

\section{New-born calf management}

Over $80 \%$ of farmers allowed a calf to remain with its dam in the CA for longer than six hours. Large nonspring calving herds were more likely than small spring calving herds to allow this occur (OR 28.1). Smaller herds, however, were more likely than larger herds to allow calves to remain in the CA for longer than six hours (OR 3.1). Unsurprisingly, a relatively strong relationship

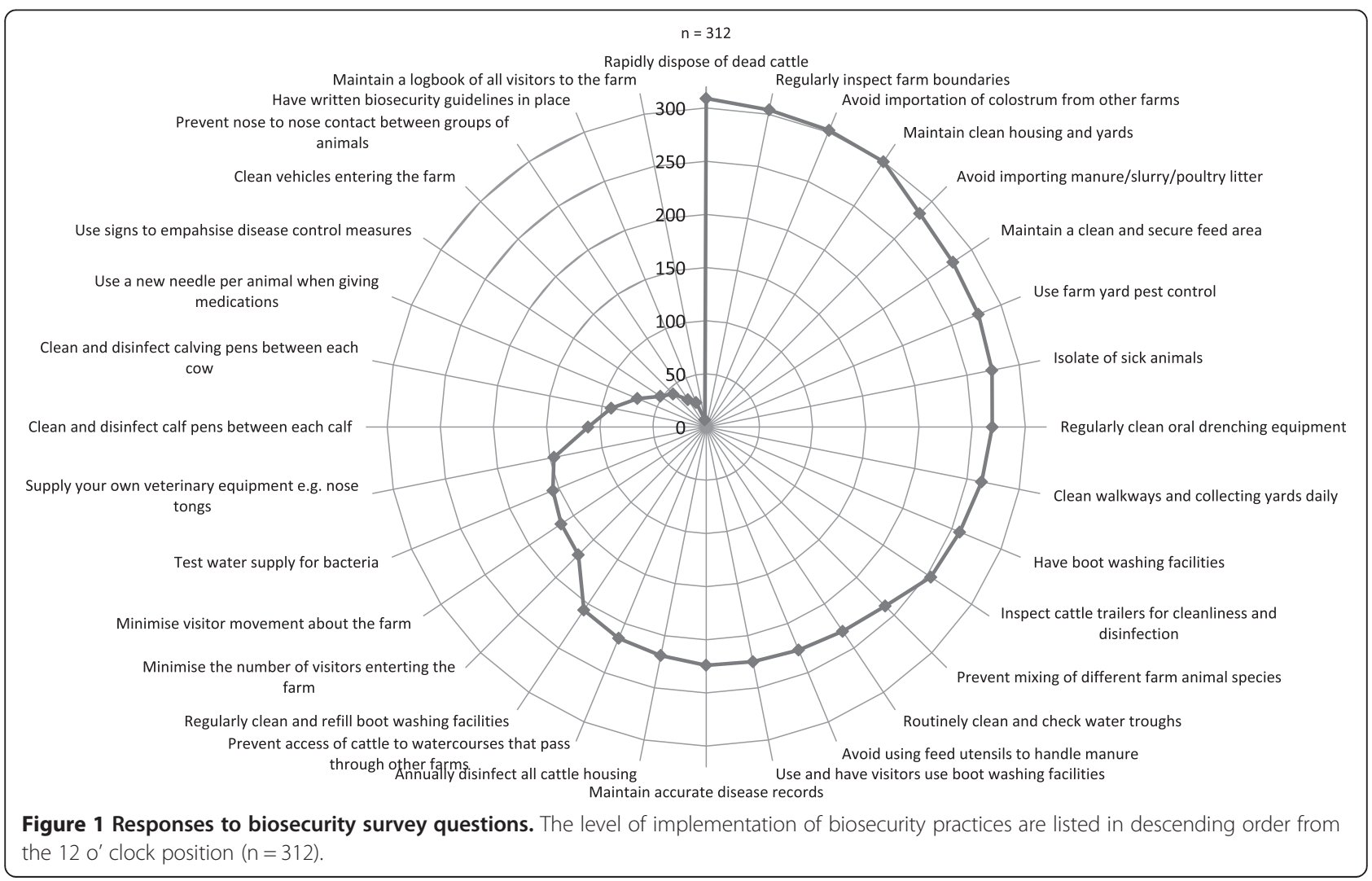


Table 2 Significant associations between independent and dependant variables (Model 1: Yes versus No)

\begin{tabular}{|c|c|c|c|}
\hline Dependent variable & Odds ratio & $P$ value & Conf. interval (95\%) \\
\hline \multicolumn{4}{|l|}{ Independent Variable } \\
\hline \multicolumn{4}{|l|}{ Is the CA overcrowded? } \\
\hline$>99$ cows vs. 66-99 cows & 5.0 & 0.001 & $1.9,13.0$ \\
\hline$>99$ cows vs. 31-65 cows & 7.8 & $<0.001$ & $2.6,23.6$ \\
\hline \multicolumn{4}{|c|}{ Do new born calves stay in CA for more than six hours? } \\
\hline $31-65$ cows vs. $>99$ cows & 3.1 & 0.009 & $0.1,0.8$ \\
\hline Non-spring $>99$ cows vs. spring $31-65$ cows & 28.1 & 0.016 & $1.9,421.4$ \\
\hline \multicolumn{4}{|c|}{ Is the CA cleaned and bedded between every calving? } \\
\hline $31-65$ cows vs. $>99$ cows & 3.6 & 0.001 & $0.1,0.6$ \\
\hline \multicolumn{4}{|l|}{ Are heifer calves fed pooled colostrum? } \\
\hline $66-99$ cows vs. $31-65$ cows & 2.2 & 0.039 & $1.0,4.5$ \\
\hline$>99$ cows vs. $31-65$ cows & 4.8 & $<0.001$ & $2.3,9.9$ \\
\hline$>99$ cows vs. 66-99 cows & 2.2 & 0.024 & $1.1,4.4$ \\
\hline \multicolumn{4}{|l|}{ Is colostrum collected without teat disinfection? } \\
\hline Mixed enterprise vs. Dairy only & 1.8 & 0.049 & $0.3,0.9$ \\
\hline \multicolumn{4}{|c|}{ Are heifer calves fed waste milk from sick cows? } \\
\hline Mixed enterprise vs. Dairy only & 2.2 & 0.009 & $1.2,3.9$ \\
\hline \multicolumn{4}{|c|}{ Do calves have direct contact with cows/ manure pre entering milking herd? } \\
\hline Non-dairy dense vs. Dairy dense & 2.5 & 0.034 & $0.2,0.9$ \\
\hline \multicolumn{4}{|c|}{ Do heifers have direct contact with cows/ manure pre entering milking herd? } \\
\hline$>99$ cows vs. 66-99 cows & 2.5 & 0.019 & $1.2,5.2$ \\
\hline \multicolumn{4}{|c|}{ Do heifers have access to pasture spread with cow slurry? } \\
\hline$>99$ cows vs. 66-99 cows & 7.5 & 0.028 & $0.1,0.9$ \\
\hline
\end{tabular}

$P$ Value: Significant $P<0.05$. CA: calving area.

was highlighted between time spent in the CA area and allowing the calf to suckle the dam $\left(r_{s} 0.5\right)$, although the vast majority of farmers (90\%) allowed the calf to suckle the dam regardless of the amount of time spent together.

Approximately $70 \%$ of respondents pooled colostrum for feeding calves and almost $90 \%$ pooled milk for the same purpose. Larger herds were more likely to pool colostrum than smaller (OR4.8) or medium sized herds (OR2.2). Feeding calves with milk from sick or mastitic cows (waste milk) was practiced in almost $60 \%$ of herds on at least an occasional basis. This was more likely to occur in mixed enterprise herds as opposed to dairy only herds (OR 2.2). Mixed enterprise herds were also more likely to collect colostrum without teat disinfection (OR 1.8). Relationships existed between those farmers pooling milk and pooling colostrum $\left(r_{s} 0.5\right)$, those feeding waste milk to calves and pooling milk for calf feeds $\left(r_{s} 0.4\right)$, and also between those feeding waste milk and those pooling colostrum $\left(r_{s} 0.3\right)$ (Table 3$)$.

\section{Hygiene and faeces management}

Direct access between young calves and adult cows or their manure was prevented by the majority of survey participants $(78.3 \%)$, however farms in non-dairy dense regions were over twice more likely to allow contact occur (OR 2.5) With regard to replacement heifers (>12 months), $78.1 \%$ of farmers allowed at least occasional direct heifer-cow contact to occur. Larger herds were more likely than medium sized herds to allow this heifer-cow contact to occur (OR 2.5). Over $70 \%$ of herds allowed young calves access to pasture which had slurry applied in the same grazing season, with almost $90 \%$ of participants allowing replacement heifers access to slurried pastures. Again larger herds were more likely than medium sized herds to allow heifers access such pasture (OR 7.5). A positive correlation existed between those herds allowing access of calves and heifers to potentially contaminated pastures $\left(r_{s} 0.5\right)$. The majority of those surveyed prevented faecal contamination (from adult cows) of both young calf and replacement heifer feed areas and water troughs ( $88.7 \%$ and $75.2 \%$ respectively).

\section{Biosecurity questionnaire descriptive analysis}

A total of 312 participants returned valid biosecurity questionnaires. Almost all study participants reported regularly inspecting farm boundaries $(97.4 \%)$, with the 
Table 3 Spearman correlation values between dependent variables

\begin{tabular}{|c|c|c|c|c|c|c|c|c|c|c|c|c|c|c|c|c|c|}
\hline & Q1 & Q2 & Q3 & Q4 & Q5 & Q6 & Q7 & Q8 & Q9 & Q10 & Q11 & Q12 & Q13 & Q14 & Q15 & Q16 & Q17 \\
\hline Q1 Is the CA used for more than one calving? & 1 & & & & & & & & & & & & & & & & \\
\hline Q2 Is the CA overcrowded? & 0.2 & 1 & & & & & & & & & & & & & & & \\
\hline Q3 Is the CA cleaned out between every calving? & 0 & -0.3 & 1 & & & & & & & & & & & & & & \\
\hline Q4 CA used to house sick cows? & 0 & 0.1 & -0.1 & 1 & & & & & & & & & & & & & \\
\hline Q5 Cows have manure soiled legs and udders? & 0.1 & 0.2 & -0.1 & 0.2 & 1 & & & & & & & & & & & & \\
\hline Q6 Calf in CA $>6$ hours & 0 & -0.1 & 0.1 & 0 & 0.1 & 1 & & & & & & & & & & & \\
\hline Q7 Calf allowed to suck from the cow? & 0 & 0.1 & 0.1 & 0.1 & -0.1 & 0.5 & 1 & & & & & & & & & & \\
\hline $\begin{array}{l}\text { Q8 Colostrum collected without disinfection of } \\
\text { the teats }\end{array}$ & 0.1 & 0.2 & -0.1 & 0.2 & 0.2 & 0.1 & 0 & 1 & & & & & & & & & \\
\hline Q9 Calves fed with pooled colostrum? & 0 & 0.2 & -0.2 & 0.2 & 0.1 & 0.1 & 0.1 & 0.3 & 1 & & & & & & & & \\
\hline Q10 Calves fed with pooled milk? & 0.1 & 0.1 & -0.1 & 0.2 & 0.1 & 0.1 & 0.1 & 0.3 & 0.5 & 1 & & & & & & & \\
\hline Q11 Calves fed with waste milk? & 0 & 0.1 & -0.2 & 0.3 & 0.2 & 0.1 & 0 & 0.3 & 0.3 & 0.4 & 1 & & & & & & \\
\hline Q12 Calf feed area contaminated with manure? & 0.1 & 0.1 & 0 & 0.1 & 0.2 & 0.1 & 0.1 & 0.2 & 0.2 & 0.1 & 0.1 & 1 & & & & & \\
\hline Q13 Direct calf/ cow contact? & 0.1 & 0.1 & -0.1 & 0.1 & 0.2 & 0.1 & 0.1 & 0.1 & 0.1 & 0.1 & 0.1 & 0.2 & 1 & & & & \\
\hline $\begin{array}{l}\text { Q14 Calves have access to pasture which has had } \\
\text { cow slurry applied? }\end{array}$ & 0.1 & 0.1 & -0.1 & 0.1 & 0.1 & 0.1 & 0.1 & 0.1 & 0.2 & 0.1 & 0.2 & 0.1 & 0.1 & 1 & & & \\
\hline Q15 Direct heifer cow contact? & 0.2 & 0.2 & -0.1 & 0.2 & 0.1 & 0.1 & 0.1 & 0.1 & 0.2 & 0.2 & 0.2 & 0.1 & 0.2 & 0.2 & 1 & & \\
\hline Q16 Heifer feed area contaminated with manure? & 0.1 & 0.2 & 0 & 0.3 & 0.3 & 0.1 & 0.1 & 0.2 & 0.2 & 0.1 & 0.1 & 0.4 & 0.2 & 0.1 & 0.3 & 1 & \\
\hline $\begin{array}{l}\text { Q17 Heifers have access to pasture which has had } \\
\text { cow slurry applied }\end{array}$ & 0.2 & 0.1 & -0.1 & 0.1 & 0.1 & 0.1 & 0.2 & 0.2 & 0.1 & 0.1 & 0.1 & 0.1 & 0.1 & 0.5 & 0.2 & 0.2 & 1 \\
\hline
\end{tabular}

Correlations $>0.3$ in bold. See Table 1 for entire list of questions.

majority also preventing access to watercourses passing through neighbouring farms (69.4\%). Cattle trailers, water troughs, and oral drenching equipment were regularly cleaned by a large proportion of farmers, $81.7 \%, 74 \%$, and $86.2 \%$ respectively. While almost $80 \%$ of farmers prevented mixing of different farm livestock species, less than $10 \%$ prevented nose to nose contact between different management age groups (i.e. cows, heifers, calves) on farm. The majority of farmers reported daily cleaning of walkways and collecting yards and also annual disinfection of all cattle housing. Only $36.2 \%$, however, reported cleaning individual calf pens between successive calves. Isolation of sick animals was reported by nearly $90 \%$, and in general, importation of colostrum and various manure types was avoided with over $90 \%$ of study farmers not engaging in such practices. Additional biosecurity practices are included in Figure 1 in order of the number of farmers implementing each measure.

\section{Discussion}

Closure of transmission routes [43] and improved calf management [8] are essential elements of MAP control at farm level. The aim of this survey was to document JD-related management practices utilised on Irish dairy farms, thereby identifying target areas for improvement in future studies and control programmes. Questions were designed to highlight management practices that have been associated with a risk of MAP transmission in the literature. In general it was found that management practices currently being implemented by Irish dairy farmers pose a high risk of MAP infection, with larger herd sizes more likely to engage in hazardous practices for MAP transmission.

Previous international studies reported an increased risk of MAP transmission in herds where more than one cow was allowed in the calving area $[17,18]$, and in herds that do not routinely clean the CA between calving's [21] . The Irish system of dairy production is an extensive, pasture-based system, with cows grazing grass outdoors for prolonged periods of lactation [44]. This combined with a relatively low average herd size compared to other countries $[42,45,46]$, might be expected to lead to a less intensive calving system with minimal CA overcrowding and good hygiene. The results presented in the current study, however, highlight that this system does not necessarily lead to optimal CA management. Pasture-based systems must operate within the constraints of the grassgrowing season, and as such, a highly seasonal calving pattern is adopted [41,47]. As compact-calving herds only experience approximately one month of concentrated calving [42], it is possible that Irish farmers invest in the infrastructural capacity to deal with herd average calving rate, as opposed to maximal calving rate, leading to overcrowding of the CA at certain times of the calving season. The sub-optimal levels of CA cleaning between calving's, and the CAs frequent use, is also potentially reflective of 
inadequate time and infrastructural resources provided to manage the period of intensive calving in spring. The fact that larger herds are less likely than smaller herds to clean (OR 0.27), and more likely to overcrowd (OR 7.8) the CA provides further support for this theory, with larger herds having more intensive calving seasons. The seasonal calving system operated in Ireland, therefore, could potentially lead to increased transmission of MAP by bringing about sub-optimal management of the CA. Education is therefore required to highlight the importance of optimal calving management, and availability of adequate resources (especially at peak calving season), and its contributing role in achieving effective control of JD.

Regarding use of the CA for isolation and treatment of sick cows, the proportion of farmers engaging in this practice in Ireland is similar to that reported internationally (approximately 50\%) [48-50]. This may again reflect increased efficiencies being sought by farmers through assigning multiple uses to existing farm infrastructure. While dual use of the CA (for both calving and hospitalisation) may be considered optimal usage of this infrastructural resource, it is placing herd-cohorts at undue risk of pathogen exposure [51]. Indeed, Norton S, Heuer $\mathrm{C}$ and Jackson $\mathrm{R}$ [52] highlighted an increased risk of MAP incidence in a herd when calves are raised in an area used for cow hospitalisation. As calves are born with naïve immune systems [53], use of the CA for cow hospitalisation does not present a rational use of farm infrastructure in regard to disease prevention and control.

Additional management practices commonly utilised on dairy farms to achieve greater resource efficiency include pooling of colostrum, pooling milk, and use of waste milk as a calf feed [54]. Colostrum is pooled to potentially provide passive immunity from vaccinated cows $[55,56]$ and to ease availability of adequate volumes of colostrum during periods of peak calving, with pooling of milk facilitating group feeding of calves. Pooling of calf feeds are highly attractive for farmers in terms of resource efficiency which may account for their extensive use on Irish farms. Additionally, Gleeson D, O'Brien B and O'Donovan $\mathrm{K}$ [57] showed that calf management labour-saving practises were more likely to be used as herd size increases. It is perhaps not surprising, therefore, that large (OR4.8) and medium (OR 2.2) sized herds in the current study were more likely to engage in the practice of pooling colostrum compared to smaller sized herds. This may also underpin the widely acknowledged increased risk of larger herds testing positive for MAP $[23,38]$ as pooling of both colostrum and milk is also associated with increased risk of MAP transmission within a herd $[14,58]$.

Waste milk may be perceived as a useful resource on dairy farms, with farmers reluctant to discard it. Waste milk can be regarded as a cost saving measure rather than using saleable milk or milk replacer as calf feeds [54] Although such feed management practices may be perceived as being resource efficient, feeding of waste milk has been associated with risk of exposure to a number of pathogens [59], including MAP [16]. More specifically, a univariate analysis completed by Barrett D, Mee J, Mullowney P, Good M, McGrath G, Clegg T and More S [38] examining risk factors for testing MAP faecal culture positive, found a significant association between pooling colostrum, feeding waste milk and testing MAP culture positive. The practice of feeding waste milk is not unique to Irish dairy farmers, however, with the current study recording a slightly lower prevalence of this practice compared to UK and Australian farmers $[60,61]$. The correlation $\left(r_{s} 0.3\right)$ between farmers in the current study that use the CA for housing sick animals, and feed waste milk to heifer calves, again supports a trend amongst farmers in seeking, and using, resource efficient management methods regardless of potential disease consequences. A balance therefore needs to be sought and promoted amongst farmers to allow practical and cost-efficient rearing of dairy calves without increasing exposure to potential harmful pathogens.

Opinions of veterinary experts and practitioners reported by Sayers R, Good M and Sayers G [62] highlights avoiding slurry importation, the up keep of farm boundaries and maintaining accurate disease records as key elements in farm biosecurity, all of which the majority of the current study participants conducted, indicating a level of good biosecurity practice implementation on farm. Veterinary experts however, ranked farmer understanding of a disease second only to maintenance of a closed herd when promoting optimum farm biosecurity [62]. While many of the JD-associated management practices used on farm appear to be resource/efficiency driven, their implementation may be due to a lack of fundamental understanding of the JD risk involved when adopting certain practices. Sayers R, Sayers G, Mee J, Good M, Bermingham M, Grant J and Dillon P [27] have reported farmers acknowledge the importance of biosecurity, but that lack of information may prevent improvement of biosecurity practices. The findings of the present study highlights the importance of ensuring farmers evaluate labour and cost saving management routines prior to their introduction on farms and are fully educated regarding potential disease transmission risks associated with such efficiencies. As this study has identified comparable management practices reported in international studies, the opportunity exists to examine how countries with more established control programmes tackled similar management issues to help limit MAP transmission.

A possible weakness of the current study is the use of self-reported responses, as evidenced by $43.3 \%$ of those surveyed reporting cows not to have manure soiled legs 
or udders. This weakness indeed highlights the need for independent on farm risk evaluation. The RAMP by AHI now provides such an independent verification and will prove extremely useful in tracking the progress of Ireland's JD control programme. In general, however, it can be concluded from this current study that a high proportion of Irish dairy farmers are engaging in practices associated with increased risk of MAP transmission. Based on existing studies, however, the prevalence of JD in Ireland, compares favourably with other milk producing nations $[31,32,63]$. The relatively small size of Irish dairy herds (average herd size 60 cows), compared to other intensive dairy systems (e.g. average herd size US:120 cows; average herd size New Zealand: 393 cows) $[42,45,46]$ may contribute to the lower recorded prevalence, larger herds being at higher risk of contracting JD [23,24,38] As Irish farmers intend to expand their dairy herds post-2015 due to the abolition of milk quotas (restriction on milk production) [64], the overall risk of contracting JD in Ireland may increase. Additionally, as it is unlikely that all expanding herds will achieve required cow numbers within the breeding capacity of their own herds, purchase of dairy stock is likely to increase further. With an already low level of closed herds operating in Ireland currently, a further increase in the purchase and movement of livestock may exacerbate the risk of MAP transmission [28]. Positively, however, Sayers R, Sayers G, Mee J, Good M, Bermingham M, Grant J and Dillon P [27] have highlighted that Irish dairy farmers with larger herds are more likely to voluntarily join a health scheme, making establishment of AHI's JD programme a timely intervention.

\section{Conclusion}

Many management practices associated with risk of MAP transmission were commonly applied on Irish dairy farms. Larger herds were more likely to engage in high risk practices for JD transmission. Control programmes should incorporate educational tools outlining the pathogenesis and transmission of MAP to highlight the risks associated with implementing certain labour-saving measures with regard to JD transmission. Programmes would also benefit from promoting evaluation of management practices, for impacts on disease control, prior to their introduction on-farm.

\section{Endnotes}

www.animalhealthireland.ie

www.myhealthyherd.com

\section{Additional file}

Additional file 1: Table S4a and b. Significant associations between independent and dependant variables (Model 2 and Model 3).
Competing interests

The authors declare that they have no competing interests.

\section{Authors' contributions}

All authors devised the study. EOD was involved in initial survey distribution and collection. RS, NB and AK were involved in data collation and analysis. All authors read and approved the final manuscript.

\section{Acknowledgements}

This Teagasc research was funded by the Irish Dairy Levy. The authors thank the farmers who gave their time to participate in this study.

\section{Author details}

${ }^{1}$ Animal \& Bioscience Research Department, Animal \& Grassland Research and Innovation Centre, Teagasc, Moorepark, Fermoy, Co. Cork, Ireland. ${ }^{2}$ Department of Biological Sciences, Cork Institute of Technology,

Bishopstown, Co. Cork, Ireland.

Received: 8 August 2014 Accepted: 11 December 2014

Published online: 24 December 2014

\section{References}

1. Ayele WY, Machackova M, Pavlik I: The transmission and impact of paratuberculosis infection in domestic and wild ruminants. Vet Med 2001, 46:205-224.

2. Raizman EA, Fetrow JP, Wells SJ: Loss of income from cows shedding Mycobacterium avium subspecies paratuberculosis prior to calving compared with cows not shedding the organism on two Minnesota dairy farms. J Dairy Sci 2009, 92:4929-4936.

3. Chi J, VanLeeuwen JA, Weersink A, Keefe GP: Direct production losses and treatment costs from bovine viral diarrhoea virus, bovine leukosis virus, Mycobacterium avium subspecies paratuberculosis, and Neospora caninum. Prev Vet Med 2002, 55:137-153.

4. Johnson-Ifearulundu YJ, Kaneene JB, Sprecher DJ, Gardiner JC, Lloyd JW: The effect of subclinical Mycobacterium paratuberculosis infection on days open in Michigan, USA, dairy cows. Prev Vet Med 2000, 46:171-181.

5. Ott SL, Wells SJ, Wagner BA: Herd-level economic losses associated with Johne's disease on US dairy operations. Prev Vet Med 1999, 40:179-192

6. Whitlock $\mathrm{RH}$, Buergelt C: Preclinical and clinical manifestations of paratuberculosis (including pathology). Vet Clin N Am Food Anim Pract 1996, 12:345-356.

7. Kudahl AB, Nielsen SS, Østergaard S: Economy, efficacy, and feasibility of a risk-based control program against paratuberculosis. J Dairy Sci 2008, 91:4599-4609.

8. Groenendaal H, Galligan DT: Economic consequences of control programs for paratuberculosis in midsize dairy farms in the United States. J Am Vet Med Assoc 2003, 223:1757-1763.

9. Windsor PA, Whittington RJ: Evidence for age susceptibility of cattle to Johne's disease. Vet J 2010, 184:37-44.

10. Sweeney RW: Transmission of paratuberculosis. Vet Clin N Am Food Anim Pract 1996, 12:305.

11. Seitz SE, Heider LE, Heuston W, Bech-Nielsen S, Rings D, Spangler L: Bovine fetal infection with Mycobacterium paratuberculosis. J Am Vet Med Assoc 1989, 194:1423-1426.

12. Doré E, Paré J, Côté G, Buczinski S, Labrecque O, Roy J, Fecteau G: Risk factors associated with transmission of Mycobacterium avium subsp. paratuberculosis to calves within dairy herd: a systematic review. $J$ Vet Intern Med 2012, 26:32-45.

13. Lombard JE: Epidemiology and Economics of Paratuberculosis. Vet Clin N Am Food Anim Pract 2011, 27:525-535.

14. Nielsen SS, Bjerre H, Toft N: Colostrum and Milk as Risk Factors for Infection with Mycobacterium avium subspecies paratuberculosis in Dairy Cattle. J Dairy Sci 2008, 91:4610-4615.

15. Streeter RN, Hoffsis G, Bech-Nielsen S, Shulaw W, Rings D: Isolation of Mycobacterium paratuberculosis from colostrum and milk of subclinically infected cows. Am J Vet Res 1995, 56:1322-1324.

16. Ridge S, Baker I, Hannah M: Effect of compliance with recommended calf-rearing practices on control of bovine Johne's disease. Aust Vet $J$ 2005, 83:85-90. 
17. Wells SJ, Wagner BA: Herd-level risk factors for infection with Mycobacterium paratuberculosis in US dairies and association between familiarity of the herd manager with the disease or prior diagnosis of the disease in that herd and use of preventive measures. J Am Vet Med Assoc 2000, 216:1450-1457.

18. Tiwari A, Vanleeuwen J, Dohoo I, Keefe G, Haddad J, Scott H, Whiting T: Risk factors associated with Mycobacterium avium subspecies paratuberculosis seropositivity in Canadian dairy cows and herds. Prev Vet Med 2009, 88:32-41.

19. Pithua P, Espejo LA, Godden SM, Wells SJ: Is an individual calving pen better than a group calving pen for preventing transmission of Mycobacterium avium subsp paratuberculosis in calves? Results from a field trial. Res Vet Sci 2013, 95:398-404.

20. Ansari-Lari M, Haghkhah M, Bahramy A, Baheran AMN: Risk factors for Mycobacterium avium subspecies paratuberculosis in Fars province (Southern Iran) dairy herds. Trop Anim Health Prod 2009 41:553-557.

21. Johnson-Ifearulundu YJ, Kaneene JB: Management-related risk factors for M. paratuberculosis infection in Michigan, USA, dairy herds. Prev Vet Med 1998, 37:41-54.

22. Hirst HL, Garry FB, Morley PS, Salman M, Dinsmore RP, Wagner BA, McSweeney KD, Goodell GM: Seroprevalence of Mycobacterium avium subsp paratuberculosis infection among dairy cows in Colorado and herd-level risk factors for seropositivity. J Am Vet Med Assoc 2004, 225:97-101.

23. Muskens J, Elbers A, Van Weering $H$, Noordhuizen J: Herd management practices associated with paratuberculosis seroprevalence in Dutch dairy herds. J Veterinary Med Ser B 2003, 50:372-377.

24. Scott HM, Sorensen O, Wu JT, Chow EY, Manninen K, VanLeeuwen JA: Seroprevalence of Mycobacterium avium subspecies paratuberculosis, Neospora caninum, Bovine leukemia virus, and Bovine viral diarrhea virus infection among dairy cattle and herds in Alberta and agroecological risk factors associated with seropositivity. Can Vet J 2006 47:981.

25. Jorgensen J: Survival of Mycobacterium paratuberculosis in slurry. Nordisk Veterinaermedicin 1977, 29:267.

26. Mee JF, Geraghty T, O'Neill R, More SJ: Bioexclusion of diseases from dairy and beef farms: risks of introducing infectious agents and risk reduction strategies. Vet J 2012, 194:143-150.

27. Sayers R, Sayers G, Mee J, Good M, Bermingham M, Grant J, Dillon P: Implementing biosecurity measures on dairy farms in Ireland. The Veterinary Journal 2012.

28. Künzler R, Torgerson P, Keller S, Wittenbrink M, Stephan R, KnubbenSchweizer G, Berchtold B, Meylan M: Observed management practices in relation to the risk of infection with paratuberculosis and to the spread of Mycobacterium avium subsp. paratuberculosis in Swiss dairy and beef herds. BMC Vet Res 2014, 10:132.

29. Dalziel TK: Chronic interstitial enteritis. BMJii, 1913:1068 - 1070

30. Groenendaal $\mathrm{H}$, Zagmutt $\mathrm{F}$ : Scenario analysis of changes in consumption of dairy products caused by a hypothetical causal link between mycobacterium avium subspecies paratuberculosis and Crohn's Disease. J Dairy Sci 2008, 91:3245-3258.

31. Good M, Clegg T, Sheridan H, Yearsely D, O'Brien T, Egan J, Mullowney P: Prevalence and distribution of paratuberculosis (Johne's disease) in cattle herds in Ireland. Ir Vet J 2009, 62:597

32. Nielsen SS, Toft N: A review of prevalences of paratuberculosis in farmed animals in Europe. Prev Vet Med 2009, 88:1-14

33. Barrett DJ, Good M, Hayes M, More SJ: The economic impact of Johne's disease in an Irish dairy herd: a case study. Ir Vet J 2006, 59:282.

34. More S: Global trends in milk quality: implications for the Irish dairy industry. Ir Vet J 2009, 62:S5.

35. More SJ, McKenzie K, O'Flaherty J, Doherty ML, Cromie AR, Magan MJ: Setting priorities for non-regulatory animal health in Ireland: results from an expert Policy Delphi study and a farmer priority identification survey. Prev Vet Med 2010, 95:198-207.

36. Richardson E, Mee J, Sánchez-Miguel C, Crilly J, More S: Demographics of cattle positive for Mycobacterium avium subspecies paratuberculosis by faecal culture, from submissions to the Cork Regional Veterinary Laboratory. Ir Vet J 2008, 62:398-405.

37. Cashman W, Buckley J, Quigley T, Fanning S, More S, Egan J, Berry D, Grant I, O'Farrell K: Risk factors for the introduction and within-herd transmission of Mycobacterium avium subspecies paratuberculosis (MAP) infection on 59 Irish dairy herds. Ir Vet $J$ 2008, 61:464.

38. Barrett D, Mee J, Mullowney P, Good M, McGrath G, Clegg T, More S: Risk factors associated with Johne's disease test status in dairy herds in Ireland. Vet Rec 2011, 168:410-410.

39. O'Doherty E, Sayers R, O'Grady L: Temporal trends in bulk milk antibodies to Salmonella, Neospora caninum, and Leptospira interrogans serovar hardjo in Irish dairy herds. Prev Vet Med 2013, 109:343-348.

40. C.S.O.: Census of Agriculture 2010- Final Results. (Office CS ed. http://www.cso.ie/en/media/csoie/releasespublications/documents/ agriculture/2010/full2010.pdf; 2012.

41. Graham DA, Clegg TA, Lynch M, More SJ: Herd-level factors associated with the presence of bovine viral diarrhoea virus in herds participating in the voluntary phase of the Irish national eradication programme. Prev Vet Med 2013, 112:99-108.

42. http://www.icbf.com/wp/wp-content/uploads/2013/07/Dairy-CalvingStats.pdf

43. Kudahl AB, Østergaard S, Sørensen JT, Nielsen SS: A stochastic model simulating paratuberculosis in a dairy herd. Prev Vet Med 2007, 78:97-117.

44. Drennan M, Carson A, Crosse S: Overview of animal production from pastures in Ireland. In Utilisation of grazed grass in temperate animal systems: proceedings of a satellite workshop of the XXth International Grassland Congress, Cork, Ireland. 2005: 19-35.

45. MacDonald JM, O'Donoghue EJ, McBride WD, Nehring RF, Sandretto CL, Mosheim R: Profits, costs, and the changing structure of dairy farming. US Department of Agriculture, Economic Research Service; 2007.

46. New Zealand Dairy Statistics 2011-2012

47. Dillon P, Crosse S, Stakelum G, Flynn F: The effect of calving date and stocking rate on the performance of spring-calving dairy cows. Grass Forage Sci 1995, 50:286-299.

48. Wells S: Biosecurity on dairy operations: hazards and risks. J Dairy Sci 2000, 83:2380-2386.

49. Vasseur E, Borderas F, Cue R, Lefebvre D, Pellerin D, Rushen J, Wade K, De Passille A: A survey of dairy calf management practices in Canada that affect animal welfare. J Dairy Sci 2010, 93:1307-1316.

50. USDA: USDA. Dairy 2007, Part III: Reference of Dairy Cattle Health and Management Practices in the United States, 2007. USDA, National Animal Health Monitoring System, Fort Collins, CO. 2008.

51. Fossler CP, Wells SJ, Kaneene JB, Ruegg PL, Warnick LD, Bender JB, Eberly LE, Godden SM, Halbert LW: Herd-level factors associated with isolation of Salmonella in a multi-state study of conventional and organic dairy farms: II. Salmonella shedding in calves. Prev Vet Med 2005, 70:279-291

52. Norton $\mathrm{S}$, Heuer $\mathrm{C}$, Jackson R: A questionnaire-based cross-sectional study of clinical Johne's disease on dairy farms in New Zealand. N Z Vet J 2009, 57:34-43.

53. Chase CC, Hurley DJ, Reber AJ: Neonatal immune development in the calf and its impact on vaccine response. Vet Clin N Am Food Anim Pract 2008, 24:87-104

54. Moore DA, Taylor J, Hartman ML, Sischo WM: Quality assessments of waste milk at a calf ranch. J Dairy Sci 2009, 92:3503-3509.

55. Saif $\mathrm{L}$, Redman DR, Smith KL, Theil KW: Passive immunity to bovine rotavirus in newborn calves fed colostrum supplements from immunized or nonimmunized cows. Infect Immun 1983, 41:1118-1131.

56. Fernandez FM, Conner ME, Hodgins DC, Parwani AV, Nielsen PR, Crawford SE, Estes MK, Saif LJ: Passive immunity to bovine rotavirus in newborn calves fed colostrum supplements from cows immunized with recombinant SA11 rotavirus core-like particle (CLP) or virus-like particle (VLP) vaccines. Vaccine 1998, 16:507-516.

57. Gleeson D, O'Brien B, O'Donovan K: The labour input associated with calf care on Irish dairy farms. Livest Sci 2008, 116:82-89.

58. Berghaus RD, Lombard JE, Gardner IA, Farver TB: Factor analysis of a Johne's disease risk assessment questionnaire with evaluation of factor scores and a subset of original questions as predictors of observed clinical paratuberculosis. Prev Vet Med 2005, 72:291-309.

59. Selim S, Cullor J: Number of viable bacteria and presumptive antibiotic residues in milk fed to calves on commercial dairies. J Am Vet Med Assoc 1997, 211:1029-1035. 
60. Brunton L, Duncan D, Coldham N, Snow L, Jones J: A survey of antimicrobial usage on dairy farms and waste milk feeding practices in England and Wales. Vet Rec 2012, 171:296-296.

61. Wraight MD, McNeil J, Beggs DS, Greenall RK, Humphris TB, Irwin RJ, Jagoe SP, Jemmeson A, Morgan WF, Brightling P, Anderson GA, Mansell PD: Compliance of Victorian dairy farmers with current calf rearing recommendations for control of Johne's disease. Vet Microbiol 2000, 77:429-442.

62. Sayers R, Good M, Sayers G: A survey of biosecurity-related practices, opinions and communications across dairy farm veterinarians and advisors. Vet J 2014, 200:261-269.

63. Manning E, Collins M: Mycobacterium avium subsp. paratuberculosis: pathogen, pathogenesis and diagnosis. Revue Scientifique et Technique (International Office of Epizootics) 2001, 20:133-150.

64. Dillon P: The Irish dairy industry - Planning for 2020. In Irish national dairy conference; Ireland. Teagasc; 2011: 1-24.

\section{Submit your next manuscript to BioMed Central and take full advantage of:}

- Convenient online submission

- Thorough peer review

- No space constraints or color figure charges

- Immediate publication on acceptance

- Inclusion in PubMed, CAS, Scopus and Google Scholar

- Research which is freely available for redistribution 